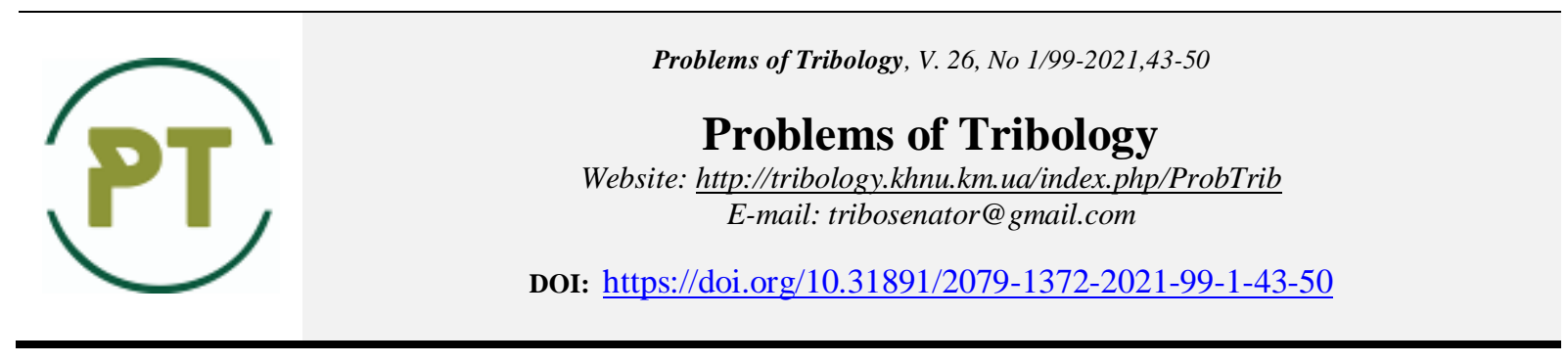

\title{
Evaluation of operational properties of aviation oils by tribological parameters
}

\author{
O.O. Mikosianchyk, O.Ye. Yakobchuk, R. H. Mnatsakanov, A.M. Khimko \\ National Aviation University, Ukraine \\ E-mail: oksana.mikos@ukr.net
}

\begin{abstract}
The quality of aviation oils was evaluated online on the basis of their lubricating, antifriction, rheological and antiwear properties in the friction contact. The use of the software and hardware complex for evaluation of operational characteristics of triboelements is offered. Approbation of the proposed methodology was performed on aviation oils SM-9. The increase in antifriction properties of the "Bora B" SM-9 oil was established to be due to the formation of limiting adsorption layers of lubricant on friction-activated contact surfaces, which are characterized by low shear stresses of the lubricant, and their structuring provides high effective viscosity in the contact at a level of $5142 \mathrm{~Pa}$.s. It was revealed that at start-up the lubricant temperature is $20{ }^{\circ} \mathrm{C}$ and the mixed lubrication mode prevails, but with increasing the lubricant temperature to $100{ }^{\circ} \mathrm{C}$ the elastic-hydrodynamic (contact-hydrodynamic) lubrication mode dominates, then at maximum rotation speed of friction pairs the hydrodynamic lubrication mode dominates, regardless of oil temperature, which indicates the effective separation of the contact surfaces due to the formation of a lubricating layer between them. Analysis of the specific work of friction in the friction contact showed that the instability of this parameter evidences to intensification of destructive processes in the near-surface layers of metal and reduction in its wear resistance. The decrease in wear resistance of the lagging surface in the conditions of rolling with sliding for all types of investigated oils is due to the different directions of the friction force vector in the contact. In the course of operation of friction pairs in nonstationary conditions, the softening of the surface metal layers occurs, which has a positive effect on the tribological processes in the contact.

The practical significance of the work consists in developing a methodology of analysis of lubricants, which makes it possible to more accurately evaluate their performance and provide recommendations for the choice of lubricant for specific friction units.
\end{abstract}

Key words: aviation oils, lubricating layer, antifriction properties, lubrication mode, wear, microhardness.

\section{Introduction}

The reliability of mechanical systems is laid at the design stage, provided during the manufacture and confirmed during the operation of machines and mechanisms. Lubricants significantly affect the reliability. The current requirements for the reliability of tribological systems are associated with the qualitative improvement of lubricants and their components, as a rule, on the basis of in-depth analysis of the lubricating medium and the contact metal surface under friction. Nowadays the technology for production of lubricants and their components is intensively developing and improving. New lubricants on mineral and synthetic base are created, serious developments on optimization of component composition of oils and lubricants are conducted and their physical, chemical and operational properties are improved.

First of all, yet at the design stage, the designer should be provided with a methodological base for not only selecting materials of machine parts according to strength criteria, but also for selecting lubricants, including assessment of temperature range of their operation, compatibility with friction pair materials, wear properties, bearing capacity of lubricating layer, tendency to form protective layers on the friction surfaces, etc.

Lubricants, when optimally selected for a specific technical problem, can exert a marked effect at the expense of saving energy, reducing wear and expenses for maintaining, increasing the service life of machinery 
and equipment, and finally, they can be a rational means of solving urgent ecological problems and environment protection [1].

Thus, the development of tools and methods for monitoring the behavior of lubricants and processes occurring in the friction contact, as well as substantiation of the criteria for their evaluation is an urgent task.

\section{Literature review}

The improvement of controlling and measuring devices and the rapid development of computer technology provide a real opportunity to study for the first time the tribological processes of formation of dissipative structures during friction at the atomic and molecular levels. For example, the SFA complex made it possible to measure film thickness to $0.1 \mathrm{~nm}$ and to record extremely small surface forces, which gives it significant advantages over other devices and thus allows one to use it as the main tool in the study of rheological, lubricating and antifriction properties of tribocontact at the nanolevel [2].

Modes and conditions of accelerated tests of motor oils in the engine have been proposed [3], which allow decreasing the time for evaluation of operational properties of oils by 8 times, in line with providing high reliability of the results of determination of washing-dispersing and anticarbon properties through selection and qualification tests of motor oils to be used in forced transport diesels.

Laboratory evaluation of physicochemical parameters, antiwear and antifriction properties of oils can confirm or refute the level of operational parameters declared by the manufacturer. In [4], based on analysis of data of industrial tests of G-Profi MSI Plus engine oil, it is shown that the oil has a sufficient resource of performance thanks to the balance of acid and alkali numbers along with effective viscosity, and this offers the possibility of prolongation of the service break time while replacing motor oils in line with the corresponding control of operational indicators.

Thus, one of the current topical trends in the area of introducig new lubricants in production is the development of an algorithm for qualification tests concerning determination of the level of oil operational properties. The scope of methods for evaluating the qualitative characteristics of oils should include both laboratory studies and model stands or installations.

In Ukraine, new technical specifications are being developed for a number of aviation lubricants. One of the most promising ones for production and introduction in practice is the mixture SM-9 [5] designed for use in gearboxes of helicopters in winter. It is composed of aviation oils AMG-10 and TSGip with a ratio of $1 / 3$ to $2 / 3$. The AMG-10 oil is produced on the basis of deeply dearomatized waxy fraction obtained from products of the hydrocracking of mixture of paraffinic oils and consisting of naphthenic and isoparaffinic hydrocarbons. It contains thickening and antioxidant additives, as well as a special organic dye. Oil for hypoid transfers TSGip belongs to the group of universal oils with antiscoring additives of high efficiency and multipurpose action. It ensures the normal operation of hypoid gears under shock loads at contact stresses above $3000 \mathrm{MPa}$ and oil temperatures in the volume up to $150^{\circ} \mathrm{C}$.

As for aviation lubricants of domestic manufacturers, it is necessary to develop measures for the introduction of them in practice (stand, flight tests, operation under supervision, etc.), aimed at evaluating the operability of aircrafts using a new oil, establishing resource and application restrictions. Upon receiving positive test results at all stages, a new brand of oil can be included in the related operation instructions.

\section{Purpose}

The aim of the work is to evaluate online the quality of aviation oils taking into account their lubricating, antifriction, rheological and antiwear properties in the friction contact.

\section{Methodology for evaluating the operational properties of oils}

The study of lubricants was carried out with using a software and hardware complex (PAC) designed to evaluate the tribotechnical characteristics of triboelements [6]. PAC is a complex, which includes a friction unit, electronic unit and software "Friction", installed on a personal computer of the IBM PC type. The software unit of mathematical data processing performs calculations according to a given calculation algorithm. The created program has a separate channel for visual assessment of the kinetics of changes in the main tribological indicators of the tribocontact in the online mode.

Methods for determining the tribological characteristics of the friction unit with using PAC are as follows:

- Lubricating properties (of hydrodynamic and non-hydrodynamic components of the lubricating film thickness) are determined by the method of voltage drop in the mode of normal glow discharge. According to this technique, the voltage drop across the lubricating layer is measured at a current of 2 and $4 \mathrm{~A}$, then the thickness of the lubricating layer is determined from the calibration tables.

- Antifriction properties of the contact are determined on the basis of data on the kinetics of changes in friction torque and subsequent calculation of the friction coefficient in the contact. 
- Rheological characteristics of lubricants (shear rate gradient, shear stress of lubricating layers, effective viscosity in the contact) are determined from the kinetics of changes in the thickness of the lubricating layer, the rolling speed of the leading and lagging surfaces and the lubricating layer temperature [7].

- Determination of the specific work of friction in the contact (through integrating the area outlined by the friction moment curve and choosing an arbitrary range of integration along on the $\mathrm{x}$-axis at a certain selected time of operation, taking into account the kinetic energy of rotating parts).

- Strength characteristics of the contact metal surfaces are determined according to GOST 22162-76 (Method for determining the microhardness).

Antiwear properties of lubricants are determined by measuring the indentation made by pressing the indenter of the device PMT-3 (GOST 27860-88. Parts of friction unit. Methods for measuring wear).

\section{Objects of research and experimental conditions}

Objects. Lubricants: sample 1 - oil "Bora B" SM-9 (TU U 19.2-38474081-017: 2018 with change 1 "Transmission oils" Bora B ") and sample 2 - Kvalitet-Avia aviation oil mixture SM-9 (TU 0253-00149878493-2005 with changes 1-13).

Material of friction pairs: rollers from steel 40ChN (analog of steel 3130H (USA), 1.5710 (Germany), 40CrNi (China)), HRC 38, Ra $0.34 \mu \mathrm{m}$. Lubrication of the contact surfaces was provided through immersing the lower roller in the lubricant bath.

Experimental conditions. Friction mode: nonstationary conditions - cyclic operation in the start-up mode - stationary operation - braking - stop (Fig. 1).

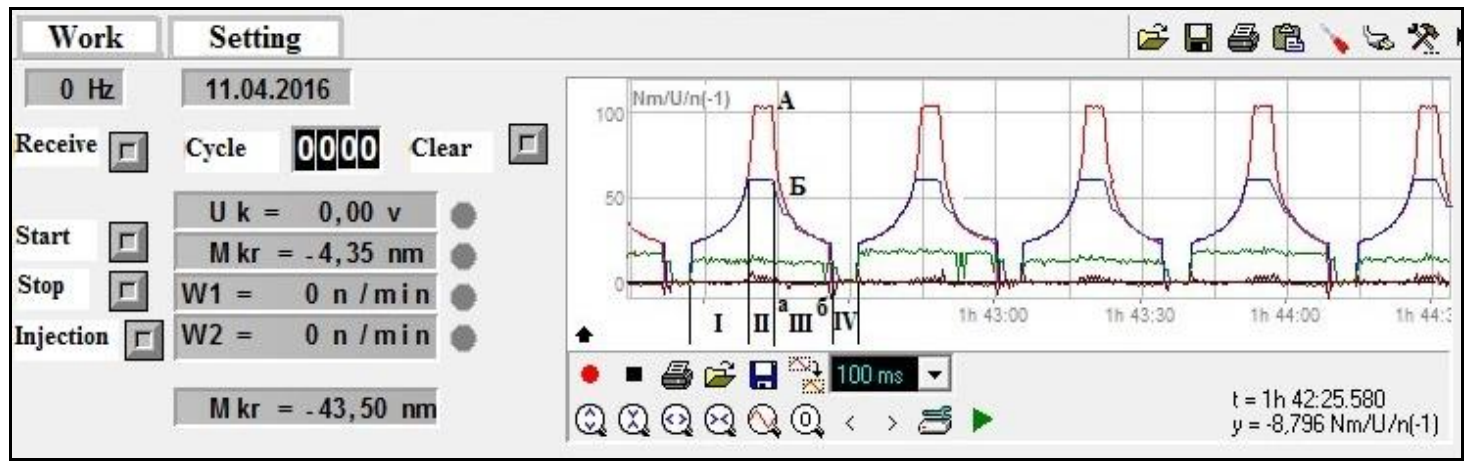

Fig. 1. Schematic representation of tribosystem operation in nonstationary conditions of friction. Areas: I - start; II - stationary work; III - braking; IV - stop.

Maximum rotation speed: $700 \mathrm{rpm}$ for the leading surface and $500 \mathrm{rpm}$ for the lagging surface. Sliding $30 \%$. Friction path for one cycle: $91.845 \mathrm{~m}$ for the leading surface and $62.8 \mathrm{~m}$ for the lagging surface. Total friction path: $9184.5 \mathrm{~m}$ for the leading surface and $6280 \mathrm{~m}$ for the lagging surface. The maximum contact load by Hertz: $200 \mathrm{MPa}$.s . Number of cycles: 100 cycles. Oil temperature: $20{ }^{0} \mathrm{C}$ from the 1 st to the 45 th cycle; heating in the $20-100{ }^{0} \mathrm{C}$ range from the 46 th to the 50 th cycle; $100{ }^{\circ} \mathrm{C}$ from the 51 st to the 100 th cycle. The duration of the cycle: $80 \mathrm{~s}$.

\section{Results}

Let us analyze the kinetics of changes in the tribotechnical parameters of aviation oils in the course of operation in nonstationary friction conditions.

Samples 1 and 2 are characterized by high antifriction properties in the investigated temperature range (Fig. 2). For sample 1, the average friction coefficient is 0.0183 , regardless of the lubricant temperature, the friction coefficient is stable, the range of its oscillations is within $0.015 \ldots 0.026$. The increase in the friction coefficient through 58 - 60 cycles is due to the change in the nature of boundary layers with increasing lubricant temperature. For sample 2, the average friction coefficient is 0.0147 , regardless of the lubricant temperature; the friction coefficient is unstable, the range of its oscillations is within $0.009 \ldots 0.034$. The established periodic increase/decrease in the friction coefficient during operation indicates the instability of tribotechnical processes in the friction contact.

Let us compare the kinetics of changes in the lubricating properties of aviation oils in the tribological contact.

The investigated oil "Bora B" SM-9 (sample 1) is characterized by effective lubricating properties both at start-up and at the maximum revolutions studied (Fig. 3). With increasing temperature in the tribological contact, the adsorption layer thickness decreases due to changes in their nature: the boundary layers of mostly physical nature are replaced by boundary layers of chemical nature, which are characterized by more effective antiwear properties. No failure of the lubricating layer during start-up and direct metal contact of the friction surfaces was 
fixed. At start-up, the lubricant temperature was $20{ }^{0} \mathrm{C}$ and the mixed lubrication mode prevailed. With increasing the lubricant temperature to $100{ }^{\circ} \mathrm{C}$ the elastohydrodynamic (contact-hydrodynamic) lubrication mode dominated, which testifies to the effective starting properties of "Bora B" SM-9 oil. At maximum speeds of the samples, the hydrodynamic mode of lubrication dominated, regardless of the oil temperature, which indicates the evident separation of the contact surfaces due to the formation of a lubricating layer.

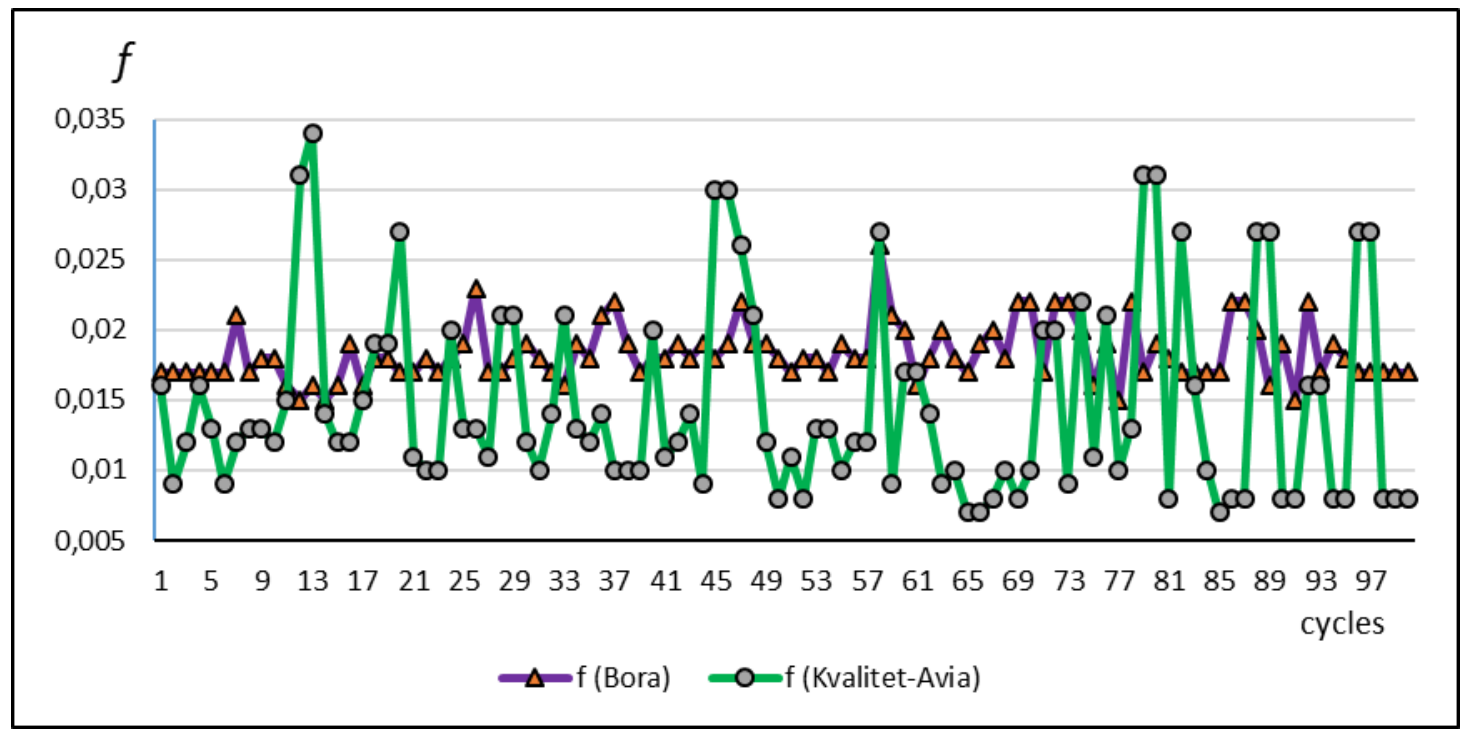

Fig. 2. The kinetics of change in the friction coefficient

Kvalitet-Avia oil mixture SM-9 (sample 2) is characterized by effective lubricating properties at the maximum studied speeds, providing a hydrodynamic mode of lubrication. The total thickness of the lubricating layer for sample 2, on average, is 1.32 times less than that of sample 1 (Fig. 3). At start-up, instability of lubrication is revealed, $20 \%$ of cycles demonstrate a dry-semidry mode of lubrication, related to the long period of formation and adaptation of the lubricant boundary layers to nonstationary friction conditions.

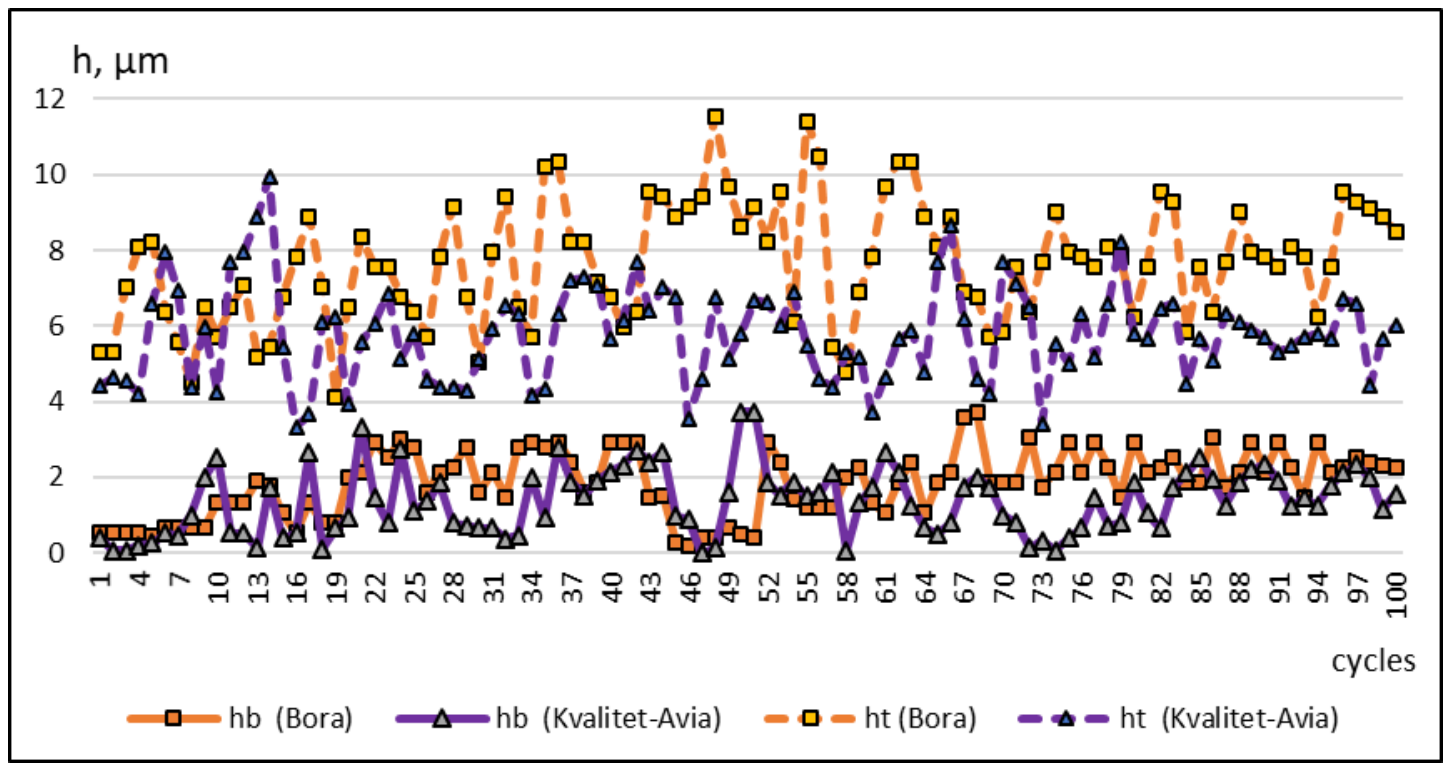

Fig. 3. Kinetics of change in the thickness of the boundary adsorption layers $\left(h_{b}\right)$ and the total thickness of the lubricating layer $\left(h_{t}\right)$ in the course of operation.

Since oils are used in helicopter transmission reducers, characterized by large contact loads and shear rate gradients, it is reasonable to analyze the rheological parameters of lubricants.

The oil "Bora B" SM-9 (sample 1) is characterized by efficient rheological properties. With it, the hydrodynamic mode of lubrication at maximum speeds of the cycle in the conditions of rolling with $30 \%$ sliding is provided owing to the high bearing capacity of the lubricant and the formation of hydro- and nonhydrodynamic components of the lubricating layer thickness, which are characterized by low shear stresses equal to $13.89 \mathrm{MPa}$ with a range of divergences within $10.91 \ldots 18.85 \mathrm{MPa}$. 
Despite high rotation speed gradients in the contact, from $1.99 .10^{3}$ to $2.26 .10^{5} \mathrm{~s}^{-1}$, which arise at a maximum sliding velocity of $0.71 \mathrm{~m} / \mathrm{s}$ in the conditions of rolling with sliding, the lubricant is characterized by high effective viscosity, on average $5142 \mathrm{~Pa} \cdot \mathrm{s}$ (Fig. 4). This indicates a high resistance of the oil components to destruction due to increasing shear rate gradient. The greatest decrease in the effective viscosity in the contact down to $378 \ldots 914 \mathrm{~Pa} \cdot \mathrm{s}$ occurs at the beginning of increasing oil temperature, i.e., during 45 - 50 test cycles. This is caused by change in the nature of the boundary adsorption levels, characterized by effective adaptation in a wide range of temperatures.

Different changes in the rheological parameters in nonstationary lubrication conditions were established for the Kvalitet-Avia oil mixture of SM-9 (sample 2). First, the average shear stress of the lubricating layer is 1.27 times less than in sample 1 and equals $10.98 \mathrm{MPa}$. However, a wide range of discrepancies were revealed in the range of $5.19 \ldots .29 .38 \mathrm{MPa}$ for this lubricant, which is due to the long-term adaptation of the lubricant boundary layers to high shear rate gradients in the conditions of rolling with $30 \%$ sliding, which reach $1.17 \cdot 10^{3}$ to $7.2 \cdot 10^{5} \mathrm{~s}^{-1}$. There is observed periodic destruction of the boundary layers in the friction contact during operation, which indicates a decrease in their antiwear properties.

Second, the low tendency to structurization of the lubricant components on the friction-activated metal surface leads to a less pronounced dependence of the effective viscosity of the oil on the shear rate gradient: the average is at the level of $500 \mathrm{~Pa} \cdot \mathrm{s}$. When the oil temperature increases to $100{ }^{\circ} \mathrm{C}$, the effective viscosity first decreases to $80 \mathrm{~Pa} \cdot \mathrm{s}$, but with further operation of friction pairs increases to $600-800 \mathrm{~Pa} \cdot \mathrm{s}$ (Fig. 4).

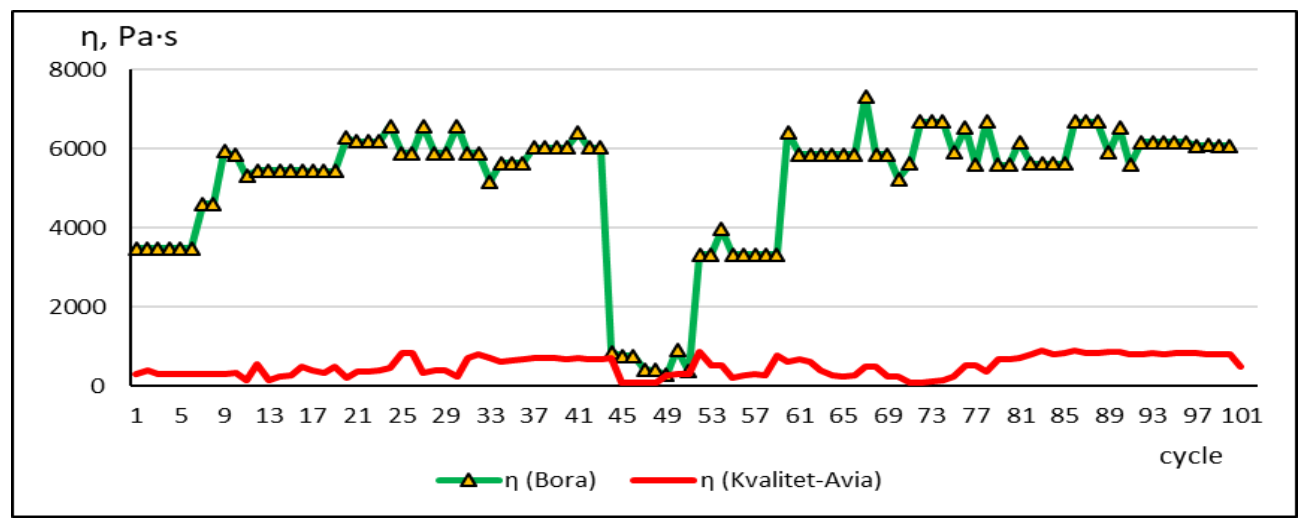

Fig. 4. The kinetics of change in the effective viscosity of oil $(\eta) n$ the contact

An important operational parameter of the tribosystem is the energy load on the friction contact, which can be evaluated from the kinetics of changes in the specific work of friction, $\mathrm{A}_{\mathrm{fr}}$. It depends on the type of lubricant, contact surface material and operation conditions of the tribosystem.

The obtained experimental values of $A_{\mathrm{fr}}$ for sample 1 in the range $1186 \ldots 6328 \mathrm{~J} / \mathrm{mm}^{2}$ indicate the normal operation conditions of the tribosystem (Fig. 5). With increasing oil temperature from 20 to $100{ }^{0} \mathrm{C}$, the specific work of friction increases, on average, by 1.6 times, which indicates transition of the tribosystem to more complex conditions of friction. However, the investigated lubricant in such conditions provides realization of the hydrodynamic mode of lubrication in the contact and high wear resistance for the metal.

For sample 2, more intense energetic processes in the friction contact were established. The specific work of friction is unstable and characterized by a wide range of oscillations in the range of $1300 \ldots 33430 \mathrm{~J} / \mathrm{mm}^{2}$, regardless of the lubricant temperature. The failure to achieve a metastable state of the tribosystem in terms of energy can lead to intensification of destructive processes in the surface layers of the metal and reduction in its wear resistance.

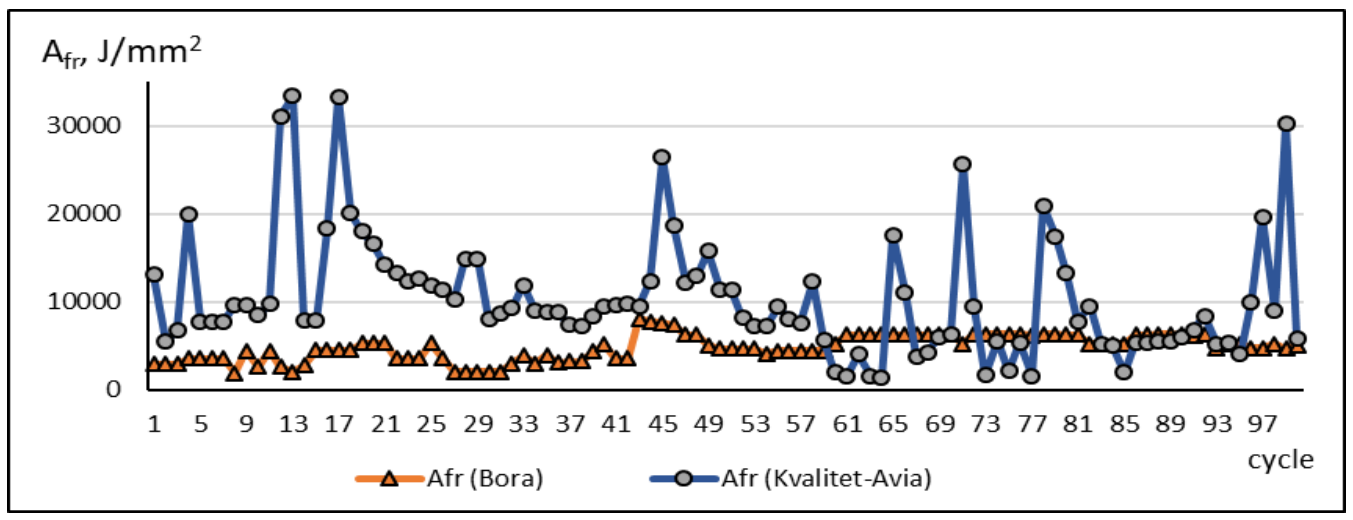

Fig. 5. Kinetics of changes in the specific work of friction in the course of operation 
One of the most important characteristics of oils during operation is their antiwear properties, so the establishment of regularities of friction pair wear will make it possible to predict its durability and reliability.

The total linear wear of the $40 \mathrm{ChN}$ steel rollers upon lubricating the friction pairs with oil is $4.9 \mu \mathrm{m}$ and $5.74 \mu \mathrm{m}$ for samples 1 and 2, respectively (Fig. 6). The wear of the lagging surface is 2.38 (sample 1) and 1.9 (sample 2) times greater than that of the leading surface, which is due, by the K.T. Trubina theory [8], to reducing the endurance limit of the lagging surface because of the increase in the rate of fatigue destruction in conditions of different directions of friction forces in the contact on the leading and lagging surfaces.

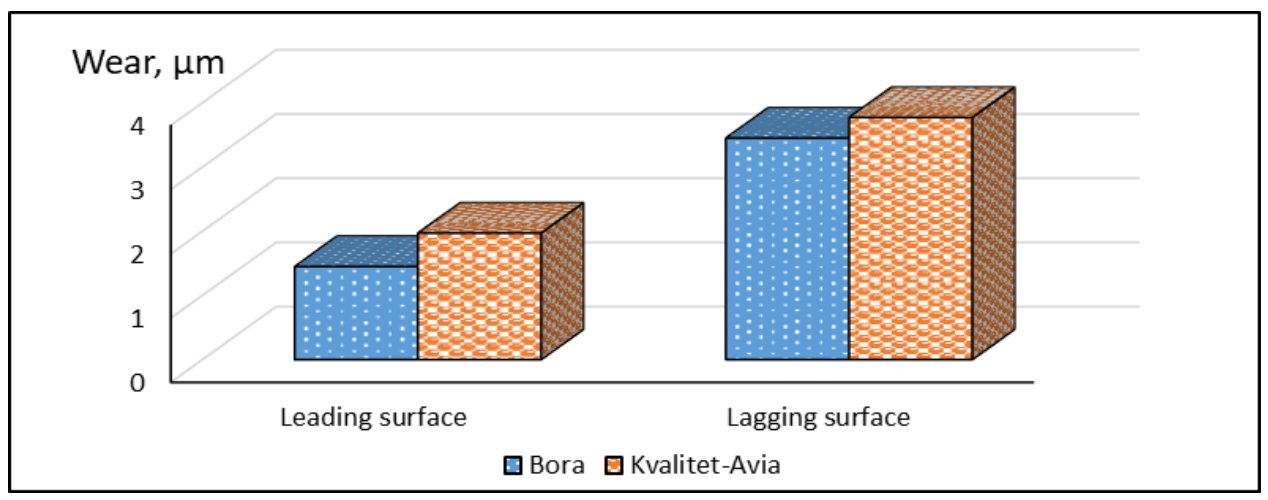

Fig. 6. Wear of contact surfaces in the course of operation

The wear intensity of both the leading and lagging surfaces is characterized by low values, which indicates high wear resistance of the contact surfaces and effective antiwear characteristics of the oils studied (Table 1). In the case of lubrication of friction pairs with sample 2, the wear intensity of the leading and lagging surfaces increases by 1.36 and 1.09 times, respectively, compared with sample 1 .

Table 1

Antiwear characteristics of aviation oils

\begin{tabular}{|c|c|c|c|c|}
\hline \multirow{3}{*}{ Indicator } & \multicolumn{4}{|c|}{ Lubricant material } \\
\hline & \multicolumn{2}{|c|}{$\begin{array}{c}\text { Sample 1 } \\
\text { Oil } \ll \text { Bora B» SM-9 }\end{array}$} & \multicolumn{2}{|c|}{$\begin{array}{c}\text { Sample } 2 \\
\text { Kvalitet-Avia oil mixture SM-9 }\end{array}$} \\
\hline & \multicolumn{4}{|c|}{ Wear of contact surfaces (steel $40 \mathrm{ChN}$ ) after 100 cycles } \\
\hline $\begin{array}{l}\text { Total linear wear of the } \\
\text { samples studied, } \mu \mathrm{m}\end{array}$ & \multicolumn{2}{|c|}{4.9} & \multicolumn{2}{|c|}{5.74} \\
\hline \multirow[b]{2}{*}{ Wear, $\mu \mathrm{m}$} & Leading surface & Lagging surface & Leading surface & Lagging surface \\
\hline & 1.45 & 3.45 & 1.97 & 3.77 \\
\hline Wear intensity & $1.57875 \cdot 10^{-10}$ & $5.49363 \cdot 10^{-10}$ & $2.14492 \cdot 10^{-10}$ & $6.00318 \cdot 10^{-10}$ \\
\hline \multirow[t]{2}{*}{ Wear resistance } & $6.33 \cdot 10^{9}$ & $1.82 \cdot 10^{9}$ & $4.66 \cdot 10^{9}$ & $1.67 \cdot 10^{9}$ \\
\hline & \multicolumn{4}{|c|}{ Microhardness of the samples (steel 40ChN) } \\
\hline $\begin{array}{l}\text { Microhardness of surface } \\
\text { before experiment, MPa }\end{array}$ & 4377 & 4590 & 4310 & 4658 \\
\hline $\begin{array}{l}\text { Microhardness of surface } \\
\text { after } 100 \text { cycles, MPa }\end{array}$ & 2764 & 2758 & 3118 & 2914 \\
\hline
\end{tabular}

Since the lubricant components affect the near-surface layers of the metal by modifying them during friction, the strength characteristics of contact surfaces were evaluated. The reduction of microhardness of steel $40 \mathrm{ChN}$ after 100 cycles was determined to be by 1.58 and 1.66 times for the leading and lagging surfaces, respectively, in the case of lubricating with sample 1; and by 1.38 and 1.6 times for the leading and lagging surfaces, respectively, in the case of lubricating with sample 2. The hardening of metal surface layers is due to the manifestation of the Rebinder effect, i.e., adsorption plasticization of solids under the action of oil surfactants. The thickness of the plasticized layer can be up to $0.1 \mu \mathrm{m}$. This phenomenon exerts a positive effect on tribological processes in the contact as it reduces the surface energy due to adsorption of the active components of the oil additive and formation of boundary adsorption layers of both physical and chemical nature. This leads to increased wear resistance of the contact surfaces at the expense of reducing the resistance of the surface layer of the solid body to plastic deformation, facilitating plastic shear in the grains and the emergence of dislocations as well as forming finer granular structure. 


\section{Conclusions}

A methodology for evaluating the operational properties of aviation oils taking into account their lubricating, antifriction, rheological and antiwear properties in the friction contact in the online mode has been developed. Based on studies of tribological characteristics of aviation oils, it was found that the oil "Bora B" SM-9 is characterized by more effective lubricating, antifriction, antiwear and rheological characteristics in nonstationary conditions of friction in the mode of rolling with $30 \%$ sliding compared with the aviation oil mixture SM -9. In particular, a comprehensive evaluation of tribological parameters of oil "Bora B" SM-9 showed the stability of the friction coefficient in the start-stop mode, formation of boundary adsorption layers of lubricant on friction-activated contact surfaces, dominance of hydrodynamic lubrication at maximum speed, high effective viscosity in the contact at low shear stresses of the oil layer and low wear intensity of friction pairs, which allows one to more accurately evaluate its operational characteristics. This, in turn, makes it possible to more accurately evaluate the quality of the oil and provide recommendations for the choice of lubricant for specific friction units.

\section{References}

1 Singh Y., Singh P., Sharma A., Choudhary P., Singla A., Singh N. (2018) Optimization of wear and friction characteristics of Phyllanthus Emblica seed oil based lubricant using response surface methodology. Egyptian Journal of Petroleum, 27 (4), 1145-1155.

2. Israelachvili J. N. (2011) Intermolecular and surface forces, 3-rd ed., USA: Academic Press, 674.

3. Bychkov V.Z., Hrytsiuk A.V., Zaitsev A.V., Klimenko N.V., Shcherbanenko G.V. (2005) Metod uskorennoy otsenki moyushchikh i antinagarnykh svoystv motornykh masel $\mathrm{v}$ dvukhtaktnom forsirovannom dizelnom dvigatele [Method for accelerated evaluation of the detergent and antinagar properties of engine oils in a two-stroke forced diesel engine]. Dvigateli vnutrennego sgoraniya, 1, 118-121.

4. Korneev S.V., Pashukevich S.V., Savoskin A.S., Shirlin I.I. (2017) Izmeneniye kharakteristik motornogo masla pri ekspluatatsii dvigateley cummins avtobusnogo parka g. Omska [Change in the characteriistics of the engine oil during operation of the cummins engines of bus fleet in the city of Omsk]. Vestnik SibADI, 2 (54), 66-69.

5. https://bora.in.ua/ukraine_import/aviamasla/tsgip.html

6. Mikosianchyk O.O. (2013) Patent 88748, Ukraine, IPC G01N 3/56. Prystrii dlia otsinky trybotekhnichnykh kharakterystyk triboelementiv [Device for estimating tribological characteristics of triboelements], 6, 4 .

7. Mikosianchyk O.O., Mnatsakanov R.G., Kindrachuk M.V. (2013) Patent 89261, Ukraine, IPC G01N 11/00. Sposib otsinky dynamichnoi efektyvnosti vyazkosti mastylnykh materialiv v trybotekhnichnomu kontakti [Method for estimating dynamic efficiency of viscosity of lubricants in tribotechnical contact], 7, 4.

8. Kurapov P.A., Novikov V.S., Efros D.G., Fedosh D.A. (2016) O mehanizme iznashivanija zubchatyh koles reduktornyh sistem gazoturbinnyh dvigatelej [On the wear mechanism of gear wheels of reduction systems of gas turbine engines]. Tribologiya - mashinostroyeniyu: Trudy XI mezhdunarodnoy nauchno-tekhnicheskoy konferentsii - Moscow: Institute for Computer Research, 137-138. 
Мікосянчик О.О., Якобчук О.Є., Мнацаканов Р.Г., Хімко А.М. Оцінка експлуатаційних властивостей авіаційних олив за триботехнічними параметрами

Проведена оцінка якості авіаційних олив 3 урахуванням їх змащувальних, антифрикційних, реологічних та протизношувальних властивостей в фрикційному контакті в режимі on-line. Запропоновано застосування програмно-апаратного комплексу для оцінки експлуатаційних характеристик трибоелементів. Апробація методики проведена на авіаційних оливах СМ-9. Встановлено підвищення антифрикційних властивостей оливи «Бора Б» СМ-9 за рахунок формування граничних адсорбційних шарів мастильного матеріалу на активованих тертям контактних поверхнях, які характеризуються низькими напруженнями зсуву мастильного шару, а їх структуризація забезпечує високу ефективну в'язкість в контакті на рівні 5142 Па·с. Проаналізовано, що при пуску, температура мастильного матеріалу 20 0С, переважає змішаний режим мащення, при зростанні температури мастильного матеріалу до 100 0С домінує еластогідродинамічний (контактно-гідродинамічний) режим мащення, при максимальних обертах пар тертя домінує гідродинамічний режим мащення, незалежно від температури оливи, що свідчить про ефективне розділення контактних поверхонь внаслідок утворення мастильного шару між контактуючими поверхнями. Аналіз питомої роботи тертя в фрикційному контакті показав, що нестабільність даного параметру свідчить про інтенсифікацію деструкційних процесів в приповерхневих шарах металу та зниження його зносостійкості. Встановлено зниження зносостійкості відстаючої поверхні в умовах кочення з проковзуванням для всіх типів досліджуваних олив, що обумовлено різновекторною направленістю сил тертя в контакті. При напрацюванні пар тертя в нестаціонарних умовах встановлено знеміцнення поверхневих шарів металу, що позитивно впливає на триботехнічні процеси в контакті.

Практичне значення роботи полягає в розробленні методики аналізу мастильних матеріалів, що дозволяє більш точно оцінити їх експлуатаційні характеристики та надати рекомендації щодо вибору мастильного матеріалу для конкретних вузлів тертя.

Ключові слова: авіаційні оливи, змащувальний шар, антифрикційні властивості, режим мащення, знос, мікротвердість 